\title{
EVALUATION OF THE IMPACT OF INTERNATIONAL TRADE USING REGRESSION AND CORRELATION MODELS
}

\begin{abstract}
The connection of international economies in the world represents an important role for the development of modern economies of countries. This phenomenon is known as globalization. The article describes in more detail the dependence of the Slovak Republic on the economies of East Asia, where mathematical research was performed on macroeconomic indicators of imports and exports. The Slovak Republic is experiencing an increase in GDP for the entire reference period. The growth of economic indicators in the Slovak Republic is ensured mainly due to the strong integration of our economy into international logistics chains and the strongly developed automotive industry. However, assuming the COVID-19 crisis, several studies suggest a sharp decline in economic indicators, as international trade has had to be significantly reduced for some time. The countries we examined in the article have a significant impact on these areas, so our research was focused on the main sectors of the Slovak economy. The automotive industry, the metallurgical industry and the electronics industry were evaluated. Data from world statistics were evaluated using mathematical and statistical models. The result of the study was the confirmation of dependence in all the categories.
\end{abstract}

Kl’účové slová: International trade, Gross Domestic Product, Export, Import, Macroecnomoics

\author{
Štefan Čarný1 \\ ${ }^{1}$ Faculty of Operational and Economics of Transport and Communications University of Žilina, \\ Univerzitná 8215/1,010 26 Žilina; +421/41 513 3434; stefan.carny@fpedas.uniza.sk \\ Vladislav Zitrický⿱ \\ ${ }^{2}$ Faculty of Operational and Economics of Transport and Communications University of Žilina, \\ Univerzitná 8215/1,010 26 Žilina; +421/41 513 3406; vladislav.zitricky@fpedas.uniza.sk
}

\section{Introduction}

The impact of globalization on the country's economic indicators is increasing every year. In order to secure global trade, it is also necessary to address the issue of functional and economically efficient logistics chains that will ensure the distribution of goods in the world evenly and at optimal costs.

At present, maritime transport is irreplaceable in transcontinental transport from Asia to the EU. The volume of transport carried out by this mode of transport cannot currently be replaced by any other mode of transport. Likewise, unit costs per unit of output represent only a fraction compared to other modes of transport.

On the other hand, it is important to note that the price or. the costs incurred per unit of transport do not mean that they are taken as a top criterion. Consumers are often willing to increase costs many times in order to ensure a faster and more efficient flow of materials or products for their business.

For the appropriate use of the railway network, it is necessary to select suitable types of goods that could be transported using the logistics chains of the railway networks. In terms of profitability, at such distances, the railway is able to halve the delivery time compared to maritime transport, which represents a possibility of more dynamic supply and, at the same time, the possibility of reducing costs.

Foreign studies show that rail transport can be suitably used as a complementary system for supplying the engineering, electrical and automotive industries in the event of a maritime supply outage. Therefore, we decided to test the two East Asian countries that are most affected by the dynamically developing manufacturing sectors. We will test partial indicators using regression analysis and their impact on the participation of the overall indicator.

\section{Evaluation of the impact of international trade using regression and correlation models}

The task of regression and correlation analysis is a mathematical description of systematic circumstances, which are accompanied by statistical dependencies. Specifically, we chose to examine the impact of foreign trade and imports of goods from Asia, and to find out whether the level of international trade with the countries of East Asia has risen to such a level that they become, for example, key trading partners for the Slovak Republic.

The aim of using regression models in research is to penetrate deeper into the essence of the observed phenomena and processes in a particular area. When solving, we get to the so-called causal links. A causal relationship between two phenomena is a state where the existence of one phenomenon is related to the existence of another phenomenon.

Our goal will therefore be to use such analytical models of dependence, which could lead to deeper research. For example, reassessing the economic benefits of switching from maritime to rail transport within logistics chains and optimizing supplies for production on the Iron Silk Road, which connects eastern Asia and Europe.

Such models are initially represented by a function of the dependence of factors that give us an insight into whether this direction of research is relevant for the next steps and for the direction of our research activities. These 
mathematical functions are called regression functions. The aim of regression analysis is to bring the empirical regression function as close as possible to the hypothetical regression function.

Before starting the research, it is necessary to perform several partial actions that require a certain degree of analytical thinking and gather them into complete blocks of information, which we can then formulate more clearly.

- Collection and mathematical formulation of the idea of the nature of the regression function,

- Formulate our ideas about the overall effect of unconsidered statistical features,

- Estimate the empirical regression function based on statistical observations,

- Assess the quality of the empirical regression function in terms of the reason and goal of the statistical survey.

\section{F-test}

To determine the dependence between the observed phenomena, the so-called F-test. An F-test is any static test in which the test statistic has a distribution of $\mathrm{F}$ assuming the validity of the null hypothesis. It is most commonly used to compare statistical models that have been estimated from a data set in order to identify the model that most closely matches the population from which the data were collected. Exact F-tests arise mainly when the models were estimated using the least squares method.

If the tabular value of the F-test is less than the calculated value, it can be stated that the investigated quantities are dependent. However, if the tabular value of the F-test is greater than the calculated value, it can be stated that the investigated quantities are not dependent. We will use the following relation to calculate the F-test value (Hindls 2006).

$$
\begin{aligned}
& F=\frac{\frac{R^{2}}{k}}{\frac{1-R^{2}}{n-k-1}} \\
& \text { Where: } \\
& \mathrm{R}^{2}-\text { is coefficient of determination } \\
& \mathrm{n}-\text { amount of observations in treatment } \\
& \mathrm{k}-\text { number of classes }
\end{aligned}
$$

\section{Data mining and its interpretation}

Gathering information from the perspective of international trade research, it is important to determine which indicators will be best for us to evaluate the market using mathematical models.

Another important fact is that information for market research is often difficult to access and therefore needs to be supplemented in some way in the form of analytical calculations, which may lead to possible deviations, but for projection, graphical representation and interpretation.

The main indicator currently used by most economists and analysts is the country's assessment of gross domestic product. Gross domestic product (at market prices), gross domestic product (at market prices), abbreviated GDP) or domestic product is the value of all final products and services produced by resident units of the observed territory (usually the state) during the observed period (usually per year). It corresponds to the so-called gross value added of the whole economy at market prices (Dolinayova 2016).

We also decided to continue by comparing the value of gross domestic product with the values of total exports and imports. To examine our dependencies, we will focus on the import curve, as Slovakia is not one of the top exporters to the PRC, and the value of imports is many times higher than the value of exports for this destination. The trend of the curves of GDP, imports and exports at first sight have common features, which at first glance changed, that their connection resp. testing of our indicators will be roughly comparable in terms of.

The basic features that have these curves the same are the local maxima and minima at certain time periods and, of course, their generally growing trend.

It can be seen from the graph that the largest increase in exports and imports for the Slovak Republic is in 2004, when Slovakia joined the EU as a member. By joining the EU and the Schengen area, we gained benefits such as duty-free contact with all EU member states, which greatly helped the overall growth of interstate transactions. The year 2009 represents the most significant decline, such a sharp fall may be related to the adoption of the new $€$ currency, this change has often accompanied other countries in the past and causes smaller revenue shortfalls. After the stabilization of our economic growth in 2011, the overall growth of the economy of the Slovak Republic also slowed down.

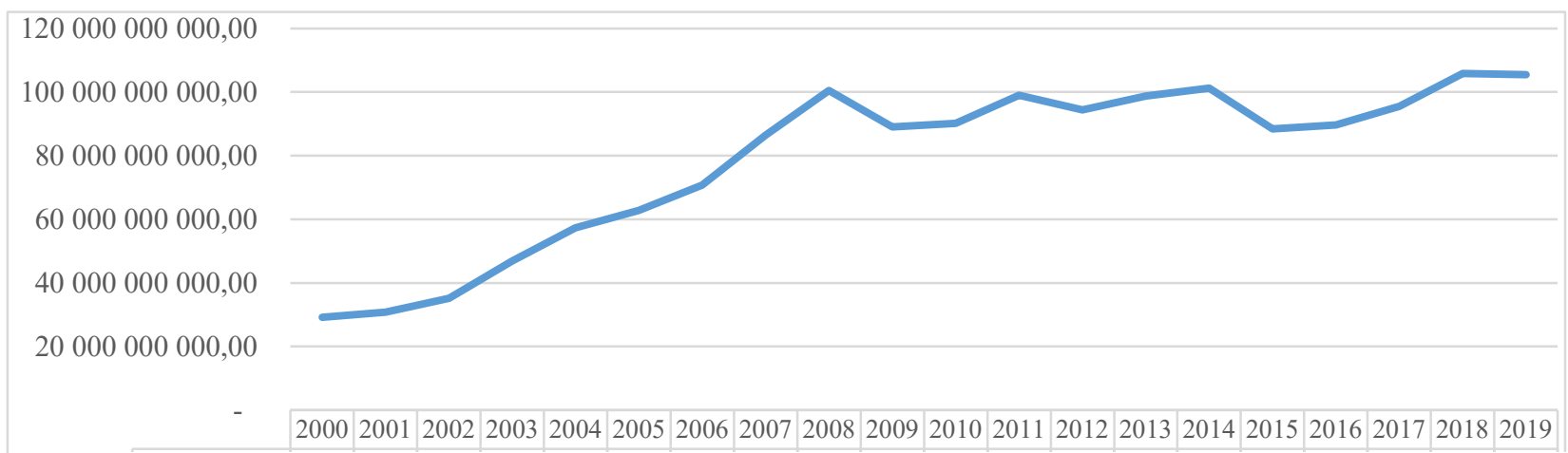

Fig. 1.GDP in Slovakia in USD (source: worldbank.com) 


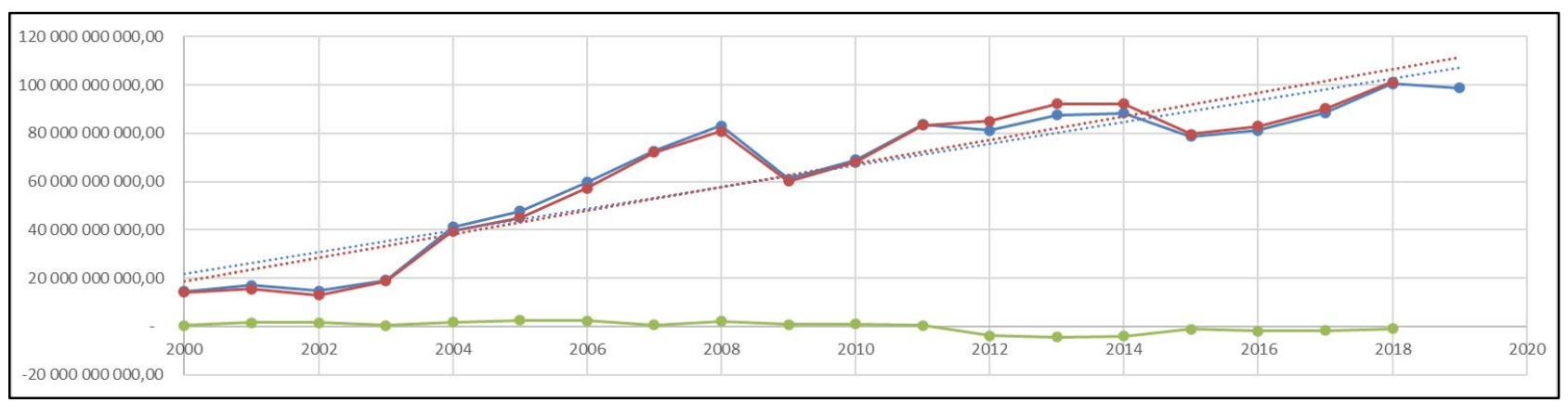

Fig. 2. Value of total Exports and Imports of the Slovak Republic for the observed period 2000-2020 (source: OEC.world)

The overall impact of the COVID-19 crisis is currently not yet described, but the models entrusted in several economic studies suggest a significant drop in 2020 , which will be carried over to the near future.

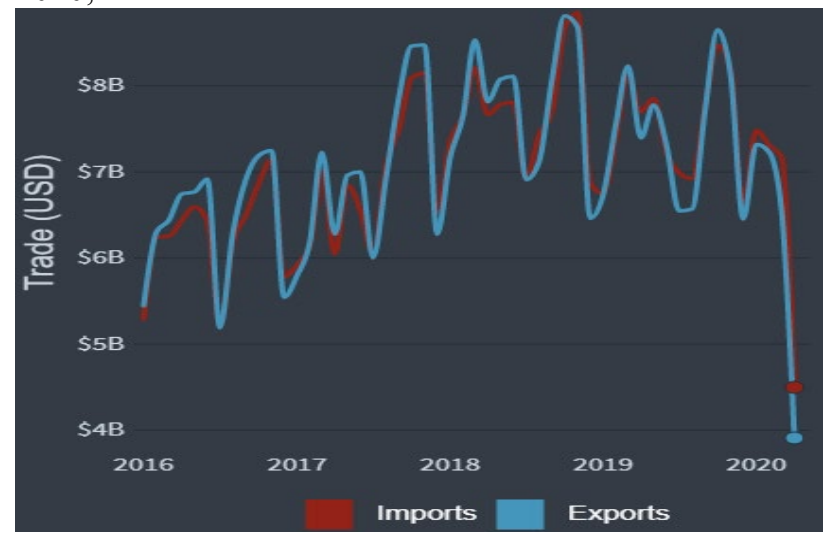

Fig. 3. An example of an OEC model in an international trade agreement for 2020 (source: OEC.world)

For further investigation, we decided to examine precisely the dependence of imports from East Asian countries. We have chosen the two largest suppliers for the Slovak Republic, namely the PRC and South Korea. By comparison, these countries are interesting in terms of connection to the European market, as China has access to Europe by sea but also by continental rail networks that cross the continent and are becoming increasingly important in terms of international trade.

On the other hand, due to the political situation for its neighboring state, South Korea has very limited opportunities in terms of the use of transcontinental rail links, and therefore South Korea's entire international trade is highly dependent only on maritime transport. The political situation between the two countries has not improved in recent years.

In picture no. 3 shows the share of the total international imports of the Slovak Republic for the countries of China and South Korea. There is approximately a comparable amount of volume throughout the period considered, except in 2012, when the difference between imports from

South Korea and China was almost two billion USD. We see the acceleration of international trade just after 2004 and 2005, when we became part of the European union. The increase in imports from South
Korea supported the arrival of the car manufacturer KIA in 2007.

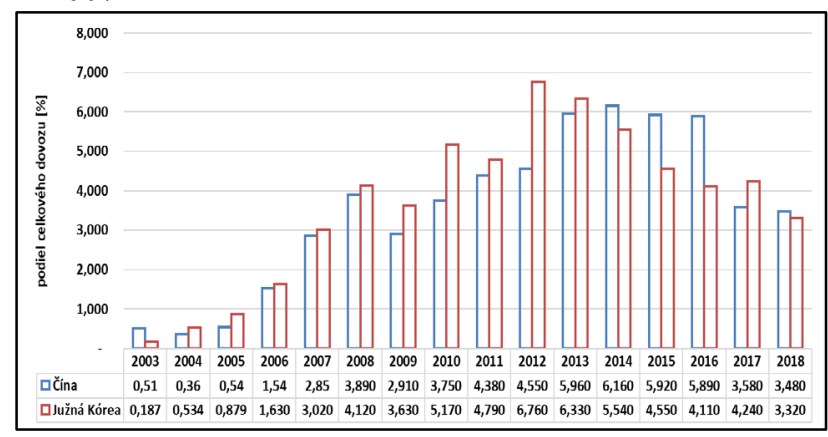

Fig. 2. Comparison of imports from the PRC and South Korea during the period considered (source: OEC.world)

\subsection{Peoples republic china import}

The PRC's impact on the local markets of individual member states has increased rapidly. The approach of technology, the expansion of electronics and current smart devices is visible daily. A significant amount of household-owned electronics is made in China. for this reason, we decided to test the main commodities that are most common in our region. In terms of international trade, we mainly import LCD displays from the PRC, which are used in several companies that produce consumer electronics, but at the same time their occurrence is increasingly being promoted in sectors other than automotive.

The blue color shows the engineering industry, and the components that were produced by machine production. Imports of these commodities often result due to lower prices, respectively. that the production of these components in our region would be expensive, and so the manufacturing capability of the PRC is used. el. transformers, electric motors, car parts or bearings.

For our research, we have selected industries or products that match as closely as possible the import comparisons of a competing country in South Korea. In our test, we chose the import of LCD displays, parts intended for the automotive industry, the import of gasoline engine units, computers, metallurgical material, and we also included the import of textiles and clothing industry, as our company is strongly influenced by this commodity. 


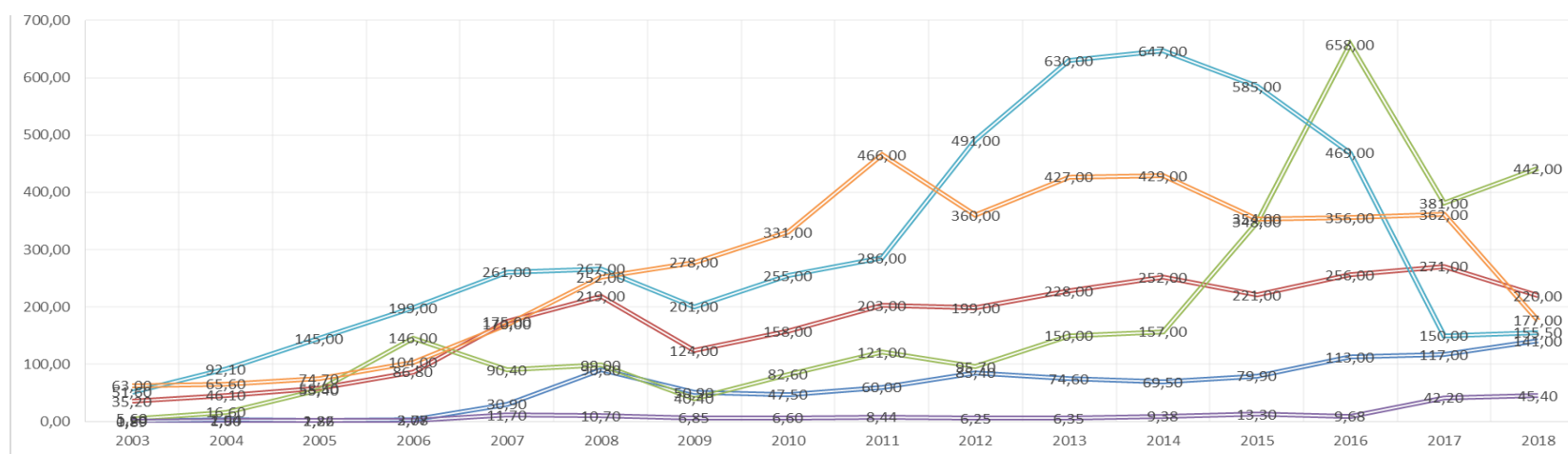

Fig. 5. Year-on-year increase in import volumes from the PRC in USD over the period considered (Source: OEC.world)

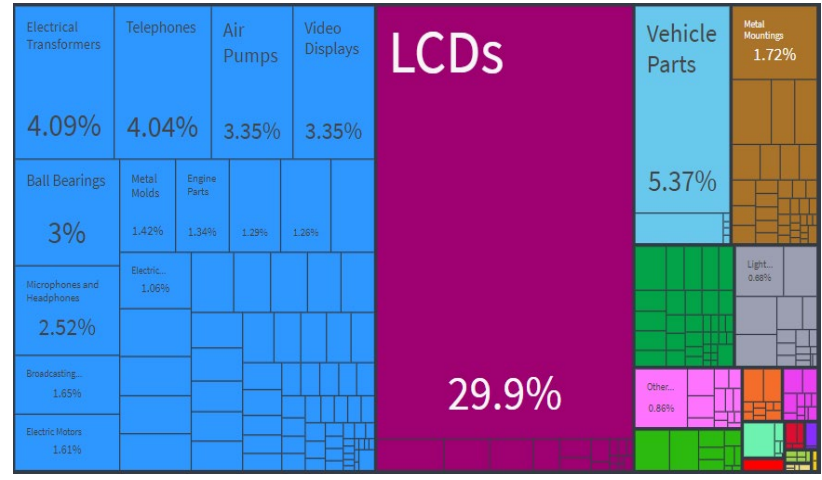

Fig. 6. Overview of imported groups of goods from China in 2018 (source: OEC.world)

Figure 6 graphically shows the course of imported goods from China for our period under review according to selected categories. An interesting trend is going through the metallurgical products sector, whose imports have caused severe complications for ironworks in the EU, with the consequences of regulating the release of externalities into the air, which has increased production. The opportunity for the growth of metallurgical material imports was stopped only by the EU anti-dumping duties, which were

Figure 5 graphically shows the course of imported goods from China for our period under review according to selected categories. An interesting trend is going through the metallurgical products sector, whose imports have caused severe complications for ironworks in the EU, with the consequences of regulating the release of externalities into the air, which has increased production. The opportunity for the growth of metallurgical material imports was stopped only by the EU anti-dumping duties, which were adopted in 2017, which resulted in a decrease in demand.

Imports of LCD panels began to rise sharply after 2014, when these displays spread to all sectors of production, from car production and the inclusion of their use in the middle and lower class car and, of course, in the electronics industry. Currently, every smart device includes at least some form of LCD display for simplified interaction with its user.

\subsection{South Korea import}

South Korea has been the second largest partner in international trade relations. Imports from South Korea are currently around 5\%. The strongest year was 2012, when general trade with South Korea has been on a declining trend. The reason why we chose South Korea for this comparison is also that in the Slovak Republic and the surrounding countries there are large conglomerates such as. Samsung, KIA or Hyundai and others. The largest items of imports are mainly engineering production, imports of electrical equipment and components and vehicles resp. automotive. Other categories include products of the metallurgical industry and the chemical industry. The year-on-year growing items are electric motors and batteries for automotive or e.g. also optical fibers.

For the purposes of our survey, we have selected commodities that match imports from the competing People's Republic of China, and we have also chosen other products and industries that are closely related to the economic sectors of the Slovak Republic.

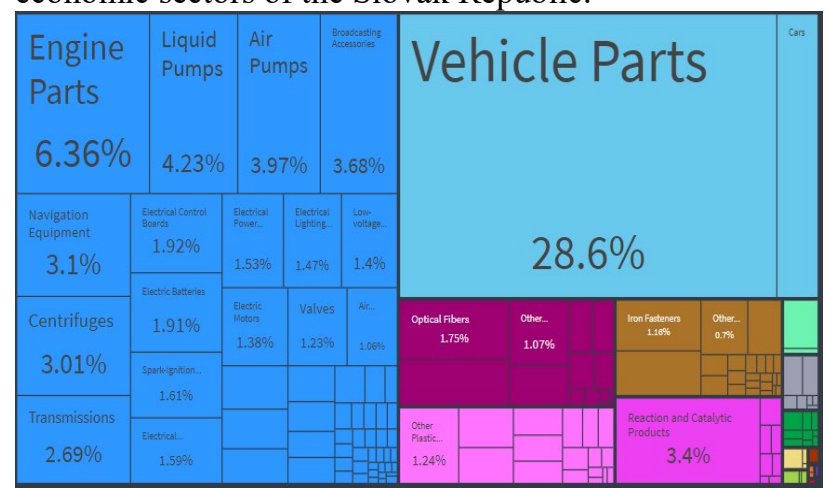

Fig. 7. Graphical representation of the largest commodities of imports from South Korea in 2019 (source: OEC.world)

Imports of products from South Korea focus on key items such as imports of displays and parts for the automotive industry. The rapid growth in the value of imported displays is related to their implementation in various devices. The decline in the volume of imported displays is probably related to the relocation of the main production of the SAMSUNG and LG conglomerate to China, where the vast majority of modern display devices began to be produced. Such steps are taken by all 


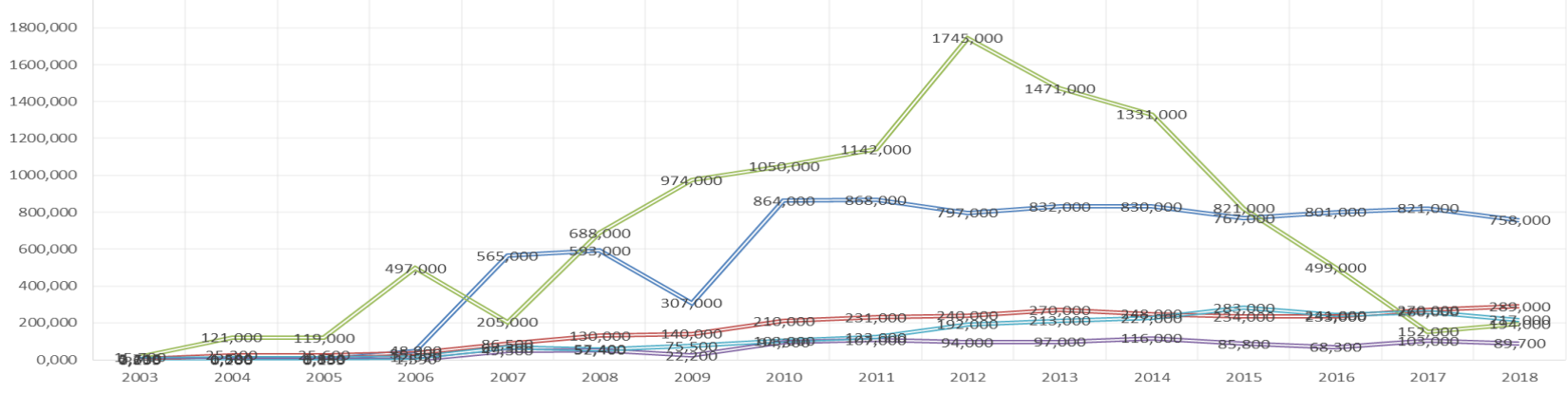

Fig. 8. Year-on-year increase in import volumes from the South Korea in USD over the period considered (Source: OEC.world)

technology companies in order to reduce the cost of their production.

Imports of goods related to the automotive industry are shown by the Autodiely curve, which recorded its first sharp increase in 2007 due to the construction of the KIA car plant in Žilina. As a result of its supply, imports of car parts from South Korea have stabilized at around USD 800 million (Oec.world 2021).

\section{Testing of statistical hypoteses for the monitored commodities of the selected sountries}

For decision-making in testing, we determine the result of the test in the form of hypotheses, which we either reject or accept. These hypotheses are listed in the following table.

Table 1 Decision table for statistical hypotheses

\begin{tabular}{|l|l|}
\hline $\mathrm{H}_{0}$ & $\begin{array}{l}\text { The GDP of the Slovak Republic depends on the } \\
\text { import of commodity XXX. From the People's } \\
\text { Republic of China }\end{array}$ \\
\hline $\mathrm{H}_{1}$ & $\begin{array}{l}\text { The GDP of the Slovak Republic is not dependent } \\
\text { on the import of commodity XXX. From the } \\
\text { People's Republic of China }\end{array}$ \\
\hline $\mathrm{H}_{0}$ & $\begin{array}{l}\text { The GDP of the Slovak Republic is dependent on } \\
\text { imports of commodity XXX. From South Korea }\end{array}$ \\
\hline $\mathrm{H}_{1}$ & $\begin{array}{l}\text { The GDP of the Slovak Republic is not dependent } \\
\text { on imports of commodity XXX. From South Korea }\end{array}$ \\
\hline
\end{tabular}

\subsection{People's Republic of China hypotheses testing}

When examining the impact of imports of textile industry products from the PRC on the GDP of the Slovak Republic, we chose a polynomial dependence, as equation $\mathrm{R} 2$ was the highest in this function. The drawn model is based on the data of picture no. 1 and figure no. 5. The graphical representation of the dependence is shown in Figure no. 6

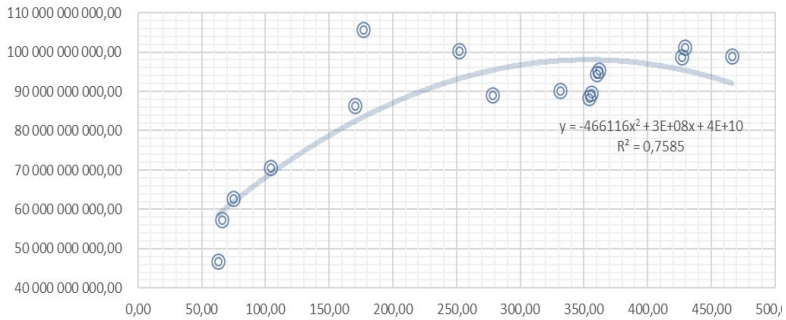

Fig. 9. Dependence of imports of textile industry products on the GDP of the Slovak Republic (source: author according to oec.com)

To verify the dependence, it is necessary to compile a table where the individual variables on the basis of which the dependence will be verified, resp. independence of the factors examined. This verification is in Table 2.

Table 2. Factor dependence verification table

\begin{tabular}{|c|l|}
\hline $\mathrm{R}^{2}$ & 0,7585 \\
\hline $\mathrm{k}$ & 2 \\
\hline $\mathrm{n}$ & 16 \\
\hline $\begin{array}{c}\mathrm{n}- \\
(\mathrm{k}+1)\end{array}$ & 13 \\
\hline $\mathrm{F}$ & 20,41511387 \\
\hline $\mathrm{F}_{\mathrm{TAB}}$ & 3,806 \\
\hline
\end{tabular}

From the table 2 we can see that the calculated value of the F-test is larger than the table value. Based on this fact, it can be concluded that it is possible to accept hypothesis $\mathrm{H} 0$ and reject Hypothesis $\mathrm{H} 1$.

The textile industry has been growing relatively steadily throughout the period under review. Its rising nature copies the GDP curve and therefore the level of reliability is around 0.7585 .

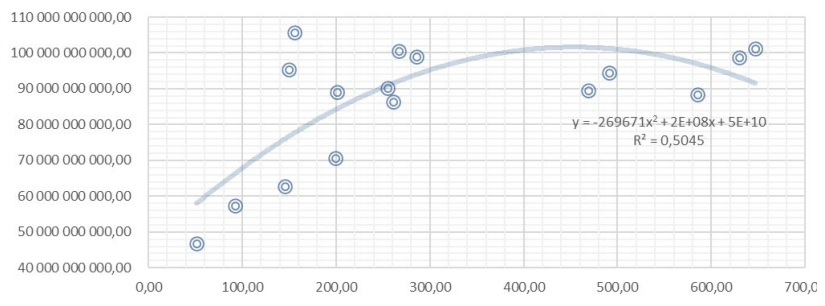

Fig. 10. Dependence of PC imports on the GDP of the Slovak Republic (source: Author according to oec.com)

To verify the dependence, it is necessary to compile a table where the individual variables on the basis of which 
the dependence will be verified, resp. independence of the factors examined. This verification is in Table 3.

Table 3 Factor dependence verification table

\begin{tabular}{|c|l|}
\hline $\mathrm{R}^{2}$ & 0,5045 \\
\hline $\mathrm{k}$ & 2 \\
\hline $\mathrm{n}$ & 16 \\
\hline $\begin{array}{c}\mathrm{n}- \\
(\mathrm{k}+1)\end{array}$ & 13 \\
\hline $\mathrm{F}$ & 6,618062563 \\
\hline $\mathrm{F}_{\mathrm{TAB}}$ & 3,806 \\
\hline
\end{tabular}

From the table 3 we can see that the calculated value of the F-test is larger than the table value. Based on this fact, it can be concluded that it is possible to accept hypothesis $\mathrm{H} 0$ and reject Hypothesis $\mathrm{H} 1$.

Imports of personal computers from China is a rapidly growing market. The confidence level is around 0,5 , which means a not very reliable indicator.

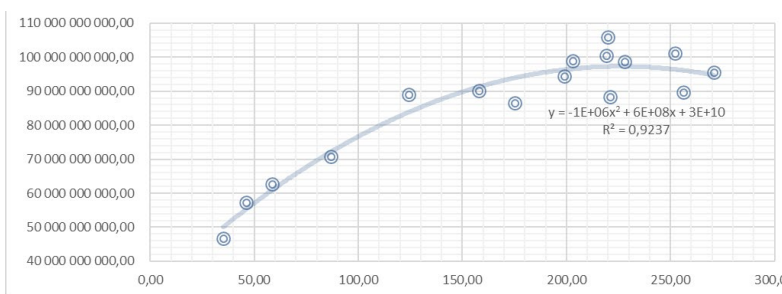

Fig. 11. Dependence of imports of metallurgical industry products on the GDP of the Slovak Republic (source: author according to oec.com)

To verify the dependence, it is necessary to compile a table where the individual variables on the basis of which the dependence will be verified, resp. independence of the factors examined. This verification is in Table 4.

Table 4. Factor dependence verification table

\begin{tabular}{|c|l|}
\hline $\mathrm{R}^{2}$ & 0,9237 \\
\hline $\mathrm{k}$ & 2 \\
\hline $\mathrm{n}$ & 16 \\
\hline $\begin{array}{c}\mathrm{n}- \\
(\mathrm{k}+1)\end{array}$ & 13 \\
\hline $\mathrm{F}$ & 78,69003932 \\
\hline $\mathrm{F}_{\mathrm{TAB}}$ & 3,806 \\
\hline
\end{tabular}

From the table 4 we can see that the calculated value of the F-test is larger than the table value. Based on this fact, it can be concluded that it is possible to accept hypothesis $\mathrm{H} 0$ and reject Hypothesis $\mathrm{H} 1$.

The metallurgical industry and its imports from the PRC are at a level of reliability of up to 0,92 , which means that imports of steel and steel products from China may be closely linked to the national economy.

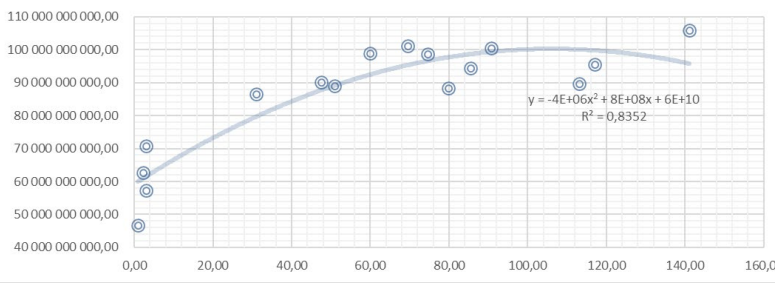

Fig. 12. Dependence of imports of parts for the automotive industry on the GDP of the Slovak Republic (source: Author according to oec.com)

To verify the dependence, it is necessary to compile a table where the individual variables on the basis of which the dependence will be verified, resp. independence of the factors examined. This verification is in Table 5.

Table 5. Factor dependence verification table

\begin{tabular}{|c|l|}
\hline $\mathrm{R}^{2}$ & 0,8352 \\
\hline $\mathrm{k}$ & 2 \\
\hline $\mathrm{n}$ & 16 \\
\hline $\begin{array}{c}\mathrm{n}- \\
(\mathrm{k}+1)\end{array}$ & 13 \\
\hline $\mathrm{F}$ & 32,94174757 \\
\hline F $_{\mathrm{TAB}}$ & 3,806 \\
\hline
\end{tabular}

From the table 5 we can see that the calculated value of the F-test is larger than the table value. Based on this fact, it can be concluded that it is possible to accept hypothesis $\mathrm{H} 0$ and reject Hypothesis $\mathrm{H} 1$.

The import of car parts from China started only after 2007, when the car manufacturer KIA was founded in Slovakia. The logistics sub-supplies of this carmaker also extend to the territory of the PRC, which means that this connection seems to be justified.

\subsection{South Korea hypotheses testing}

We selected the survey of imported commodities from South Korea according to their impact on our national economy. We know that the dependence of imports is linked to the national economy, but the strength of this dependence may be increased when examining articles that are somehow directly linked to key enterprises, e.g. KIA, SAMSUNG (Trembošova 2019).

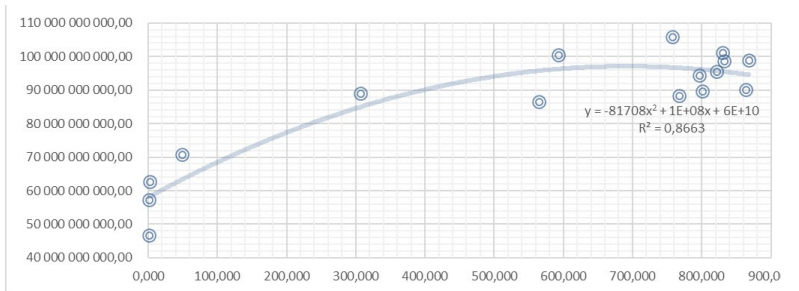

Fig. 13. Dependence of imports of automotive parts from South Korea on the GDP of the Slovak Republic (source: Author according to oec.com)

To verify the dependence, it is necessary to compile a table where the individual variables on the basis of which the dependence will be verified, resp. independence of the factors examined. This verification is in Table 6. 
Table 6. Factor dependence verification table

\begin{tabular}{|c|l|}
\hline $\mathrm{R}^{2}$ & 0,8663 \\
\hline $\mathrm{k}$ & 2 \\
\hline $\mathrm{n}$ & 16 \\
\hline $\begin{array}{c}\mathrm{n}- \\
(\mathrm{k}+1)\end{array}$ & 13 \\
\hline $\mathrm{F}$ & 42,11630516 \\
\hline $\mathrm{F}_{\mathrm{TAB}}$ & 3,806 \\
\hline
\end{tabular}

From the table 6 we can see that the calculated value of the F-test is larger than the table value. Based on this fact, it can be concluded that it is possible to accept hypothesis $\mathrm{H} 0$ and reject Hypothesis $\mathrm{H} 1$.

Imports of car parts from South Korea, on the other hand, operate in a stable supply mode. Its value is stable, which follows from Figure no. 7. The confidence level is 0,8663 .

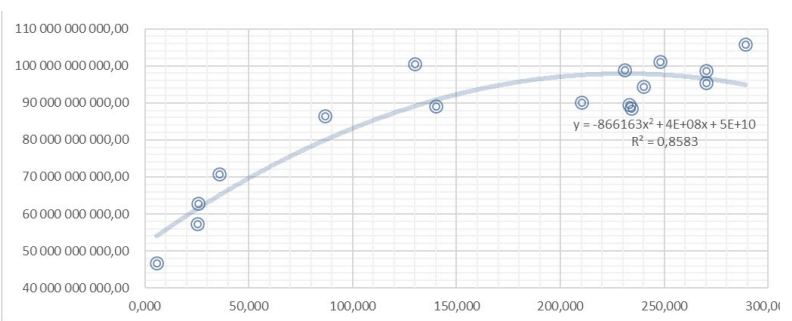

Fig. 14. Dependence of imports of metallurgical industry products from South Korea on the GDP of the Slovak Republic (source: Author according to oec.com)

To verify the dependence, it is necessary to compile a table where the individual variables on the basis of which the dependence will be verified, resp. independence of the factors examined. This verification is in Table 7 .

Table 7. Factor dependence verification table

\begin{tabular}{|c|l|}
\hline $\mathrm{R}^{2}$ & 0,8583 \\
\hline $\mathrm{k}$ & 2 \\
\hline $\mathrm{n}$ & 16 \\
\hline $\begin{array}{c}\mathrm{n}- \\
(\mathrm{k}+1)\end{array}$ & 13 \\
\hline $\mathrm{F}$ & 39,37155963 \\
\hline $\mathrm{F}_{\mathrm{TAB}}$ & 3,806 \\
\hline
\end{tabular}

From the table 7 we can see that the calculated value of the F-test is larger than the table value. Based on this fact, it can be concluded that it is possible to accept hypothesis $\mathrm{H} 0$ and reject Hypothesis $\mathrm{H} 1$.

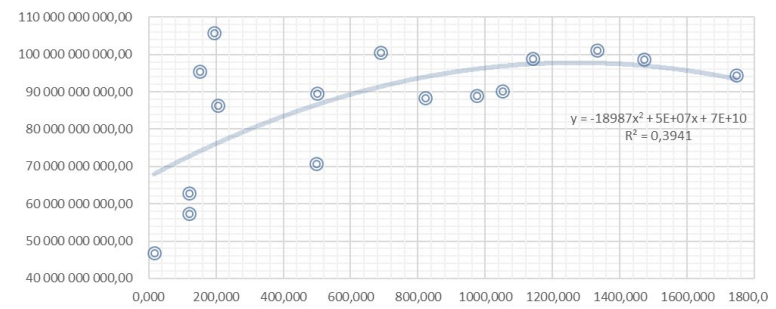

Fig. 15. Dependence of imports of LCD screens from South Korea on the GDP of the Slovak Republic (source: Author according to oec.com)
To verify the dependence, it is necessary to compile a table where the individual variables on the basis of which the dependence will be verified, resp. independence of the factors examined. This verification is in Table 8 .

Table 8. Factor dependence verification table

\begin{tabular}{|c|l|}
\hline $\mathrm{R}^{2}$ & 0,3764 \\
\hline $\mathrm{k}$ & 2 \\
\hline $\mathrm{n}$ & 16 \\
\hline $\begin{array}{c}\mathrm{n}- \\
\mathrm{k}+1)\end{array}$ & 13 \\
\hline $\mathrm{F}$ & 3,9233483 \\
\hline $\mathrm{F}_{\mathrm{TAB}}$ & 3,806 \\
\hline
\end{tabular}

From the table 8 we can see that the calculated value of the F-test is larger than the table value. Based on this fact, it can be concluded that it is possible to accept hypothesis $\mathrm{H} 0$ and reject Hypothesis $\mathrm{H} 1$.

Screen imports from South Korea represent the weakest dependency at only 0,3764 . The reason is sharp fluctuations in the volume of imports, which behave too jumpy, which does not correspond too much with stable economic growth.

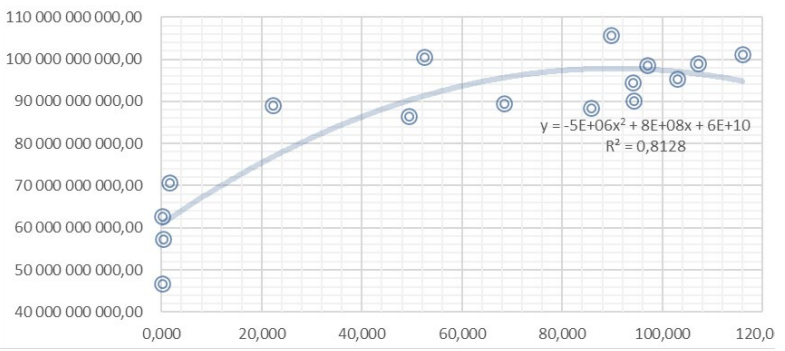

Fig .13. Dependence of automotive imports from South Korea on the GDP of the Slovak Republic (source: Author according to oec.com)

To verify the dependence, it is necessary to compile a table where the individual variables on the basis of which the dependence will be verified, resp. independence of the factors examined. This verification is in Table 9.

Table 9. Factor dependence verification table

\begin{tabular}{|c|l|}
\hline 9 & 0,8128 \\
\hline $\mathrm{k}$ & 2 \\
\hline $\mathrm{n}$ & 16 \\
\hline $\begin{array}{c}\mathrm{n}- \\
(\mathrm{k}+1)\end{array}$ & 13 \\
\hline $\mathrm{F}$ & 28,22222222 \\
\hline $\mathrm{F}_{\mathrm{TAB}}$ & 3,806 \\
\hline
\end{tabular}

From the table 9 we can see that the calculated value of the F-test is larger than the table value. Based on this fact, it can be concluded that it is possible to accept hypothesis $\mathrm{H} 0$ and reject Hypothesis $\mathrm{H} 1$.

Engine parts imported from South Korea have the same course as car parts but differ only in value. The level of significance is at the level of 0,8128 , which means that the import of this article is strongly related to the development of our national economy. 


\section{Conclusion}

International trade from the countries of East Asia is strongly preferred in the conditions of the Slovak Republic. Products, products and materials that are imported into the territory of the Slovak Republic are often many times cheaper, whether they are consumer products or material or raw materials as inputs to production processes.

By evaluating the regression models and their impact on the national economy, in particular GDP, we found that all the commodities we chose from both countries examined partly contribute to GDP growth. The reason is the strong orientation of the Slovak Republic towards industrial production. The import of material ensures a smooth production process, which in turn ensures sufficient jobs for the population and the associated cycle of the national economy.

At present, the trend of imports from East Asian countries is slightly declining, as we have declared in the market analysis, but this phenomenon is only a presumption of a cyclical economic crisis, after which the market mechanism is likely to reopen and import volumes return to their level.

However, the import of goods from abroad also brings with it risks, e.g. in the metallurgical industry, which employs a large number of economically active people in the Central EU region. In the event of a sharp increase in imports and a decrease in local production, such steps could mean a gradual reduction in production for the metallurgical industry. Similar cases may occur in other sectors, so it is important that it grows internationally and supports each other with the national economy through synergy effects.

\section{References}

Dolinayova A., Nedeliakova E., Brumerčíková E., 2016 Ekonomika železničnej dopravy Žilina: Žilinská univerzita, 180p. ISBN 978-80-554-1283-2

Hindls, R, et. al. 2006 Statistika pro ekonomy. Praha : Professional Publishing ISBN 808-69-461-69

https://oec.world/ - 10.5 2021. https://oec.world/en/profile/country/svk?tradeScaleSelect or $1=$ tradeScale 2

https://oec.world/ - 11. 5 2021. https://oec.world/en/profile/bilateralcountry/svk/partner/chn

https://oec.world/ -15.5 2021. https://oec.world/en/profile/bilateralcountry/svk/partner/kor

https://oec.world/// https://oec.world/. - 10. 5 2021. https://oec.world/en/profile/country/svk.

Ministerstvo hospodárstva Slovenskej republiky https://www.mhsr.sk/. - 18. 5.2021. https://www.mhsr.sk/uploads/files/ezNh8gXF.pdf.

Strapáč Martin [Online] // Biznisklub.sk. - 10.. Jún 2020. https://biznisklub.sk/wpcontent/uploads/2018/11/Anal\%C3\%BDzaHutn\%C3\%ADcky-priemysel.pdf.

Dzian, M., Paluš, H., \& Parobek, J. (2020). The impact of globalisation on the slovak timber trade. Paper presented at the Sustainability of Forest-Based Industries in the Global Economy - Proceedings of Scientific Papers, 45-49.

Trembošová, M., Dubcová, A., \& Štubňová, M. (2019). The specifics of retail network's spatial structure in the city of žilina. Geographia Cassoviensis, 13(2), 228-245. doi:10.33542/GC2019-2-07

Ubrežiová, I., Kapsdorferová, Z., \& Sedliaková, I. (2012). Competitiveness of slovak agri-food commodities in third country markets. Acta Universitatis Agriculturae Et Silviculturae Mendelianae Brunensis, 60(4), 379-386. doi:10.11118/actaun201260040379 